\title{
Influence of pasture management on soil biological quality
}

\author{
MANAS R. BANERJEE, DAVID L. BURTON, W. P. (PAUL) MCCAUGHEY, AND C.A. GRANT
}

Authors are post doctoral research associate and associate professor Department of Soil Science, University of Manitoba, Winnipeg, Manitoba, Canada R3T 2N2; and scientists at Agriculture and Agri-Food Canada, Research Centre, Brandon, Manitoba, Canada R7A 5Y3

\begin{abstract}
The long-term sustainability of pasture management systems, whether related to structural stability or nutrient dynamics, is dependent upon maintaining soil biological properties. This study investigates the extent to which the microbiological and biochemical properties of soil can change with season and pasture management system, including their likely value as indicators of soil quality. The experiment was conducted on a 30-ha pasture near Brandon, Manitoba. Seasonal fluctuations were observed in the soil microbial and biochemical properties. In general, these fluctuations were mainly independent of the small variations in soil organic matter content but were more closely related to soil water content. The data also suggests an impact of stocking rate and grazing system on soil microbial biomass $\mathrm{C}$ and on $\mathbf{N}$ mineralization potential. However, because duration of the investigation, limited number of replications and the high soil variability encountered, it is not yet possible to recommend any particular grazing system and/or stocking rate favorable for the maintenance of soil biological quality. The trends suggest that light, continuous grazing systems had the largest microbial biomass and nutrient mineralizing activity.
\end{abstract}

Key Words: Microbial biomass carbon, soil enzyme activity, grazing system, stocking rate, rotational grazing

The grazing of pasture and range lands by livestock is common practice in Canada and elsewhere and grazing management systems have been shown to influence the soil-plant ecosystem (Warren et al. 1986). The duration and intensity of grazing may affect conservation of soil, water and biological organisms. It has been suggested that the inclusion of a livestock component might play a significant role in increasing the long-term sustainability of agricultural ecosystems (Magdoff 1995). According to Hart and Hoveland (1989) grazing livestock exert 4 primary effects on pasture: a) Defoliation of herbage reduces photosynthetic capacity and may reduce root development, carbohydrate storage, and $\mathrm{N}_{2}$ fixation. b) Selectivity for plant parts and plant species in a mixed stand may affect relative productivity and persistence of the species present and invasion of undesirable species. c) Trampling damages plant tissue, increases soil bulk density, and slows water infiltration. d) Excretion concentrates urine and dung in small areas and affects plant palatability and nutrient cycling.

Grazing systems may contribute to maintaining high forage nutritional value on pastures (Howarth and Goplen 1983). The quality of forage sustained in rotationally stocked pastures has

Accepted 11 Mar. 1999

\section{Resumen}

La sustentabilidad a largo plazo de los sistemas de manejo de potreros, ya sea relacionados a la estabilidad estructural o la dinámica de nutrientes, depende de mantener las propiedades biológicas del suelo. Este estudio investigo la cantidad a la que las propiedades microbiológicas y bioquímicas del suelo pueden cambiar con la estación y el manejo del potrero, incluyendo su valor probable como indicadores de la calidad del suelo. El experimento se condujo en un potrero de 30 ha cerca de Brandon, Manitoba. Se observaron las fluctuaciones estacionales de las propiedades microbianas y bioquímicas del suelo. En general, estas fluctuaciones fueron principalmente independientes de las pequeñas variaciones del contenido de materia orgánica, pero estuvieron muy relacionadas al contenido de agua del suelo. Los datos también sugieren un impacto de la carga animal y del sistema de apacentamiento en la biomasa microbiana y el potencial de mineralización de carbón y nitrógeno. Sin embargo, debido a la duración de la investigación, el limitado número de repeticiones y la alta variabilidad encontrada, no es posible recomendar un sistema de apacentamiento y/o una carga animal favorable para mantener la calidad biológica del suelo. Las tendencias sugieren que una carga ligera con el sistemas de apacentamiento continuo tuvo la mayor biomasa microbiana y la mayor actividad mineralizante de nutrientes.

been reported to be greater than that in pastures stocked continuously (Walton et. al. 1981), but in both rotational and continuous systems, seasonal fluctuations in forage quality have been noted (Jung et al. 1985). Sharrow (1983) demonstrated that better nutrition is provided to animals in rotationally than continuously stocked paddocks, because amounts of plant biomass are greater. Grazing system and stocking intensity experiments in pasture research have focused on livestock weight gains, and forage quality and quantity (Langlands and Bennett 1973, Walton et al. 1981, Jung et al. 1985). However, the nutritional quality and quantity of forages in pasture also depend on the quality of the soil in which they grow. The maintenance and improvement of soil quality is fundamental to sustaining soil fertility and productivity. Soil microbial and biochemical properties are related to soil fertility and productivity. The extent to which these properties can change with season or pasture management system is of interest from several viewpoints, including their likely value as indicators of soil quality (Doran and Parkin 1994). Thus, livestock grazing and stocking rate might affect soil microbial activities and their role in nutrient transformation in pasture land. Our object was to determine the effects of grazing system (including stocking rate) and season on microbial and biochemical properties of soil. 
The soil biota is the main driving force behind nutrient and energy transformations in soil. Through the production of enzymes, soil organisms mediate the major catalytic processes in soil as well as being themselves substrates for decomposition. The microbial community inhabits the soil environment, responding to physical, chemical or biological perturbation. Soil biological properties were chosen to represent the soil environment in which organisms must exist (soil organic matter content, water content), the microbial community itself (microbial biomass $\mathrm{C}$ and $\mathrm{N}$ content) and biochemical activity of the microbial population ( $\mathrm{N}$ mineralization, arylsulfatase and phosphatase). The biochemical activities were chosen to be representative of the major nutrients $(\mathrm{N}, \mathrm{P}$ and $\mathrm{S}$ ) which influence plant productivity. In this work we evaluate the magnitude and change in these properties, albeit over a limited time frame, and interpret these findings in the context of soil quality and productivity.

\section{Materials and Methods}

The experiment was conducted on a 30ha pasture near Brandon, Manitoba (49 ${ }^{\circ}$ $52^{\prime} \mathrm{N}$; $99^{\circ}$ 59' W; Elevation $363 \mathrm{~m}$ above sea level). Initially, the pasture consisted of approximately $70 \%$ alfalfa (Medicago sativa L.), $25 \%$ meadow bromegrass (Bromus biebersteinii Roem and Schult.) and 5\% Russian wildrye (Psathyrostachys juncea (Fisch.) Nevski). The area was seeded in 1990 and pastures were fertilized with N, P, K, and S to meet Manitoba provincial soil test recommended levels. The site was located on an Orthic Black Chernozem soil rated as class 5 Souris fine sandy loam soil (Ehrlich et al. 1957) Analysis for plant macronutrients was conducted by NorWest labs and indicated the following results: $\mathrm{N}, 14.0 \mathrm{~kg} \mathrm{ha}^{-1}$ $\left(\mathrm{CaCl} 2\right.$ extract); $\mathrm{P}, 40.1 \mathrm{~kg} \mathrm{h \textrm {h } ^ { - 1 }}$ $\left(\mathrm{NH}_{4} \mathrm{C}_{2} \mathrm{H}_{3} \mathrm{O}_{2} / \mathrm{CH}_{3} \mathrm{COF}\right.$ extract); K, 256.4 $\mathrm{kg} \mathrm{ha}^{-1}\left(\mathrm{NH}_{4} \mathrm{C}_{2} \mathrm{H}_{3} \mathrm{O}_{2} / \mathrm{CH}_{3} \mathrm{COF}\right.$ extract); and $\mathrm{S}, 21.1 \mathrm{~kg} \mathrm{ha}^{-1}\left(\mathrm{CaCl}_{2}\right.$ extract). The area was subdivided into eight, 3.7-ha pastures, which were allocated to a factorial combination of treatments, consisting of 2 stocking rates $(\mathrm{H}$, heavy; 8 steers per pasture, or 2.2 steers $\mathrm{ha}^{-1}$; and L, light; 4 steers per pasture, or 1.1 steers ha $\left.{ }^{-1}\right)$ and 2 grazing intensities $(\mathrm{C}$, continuous and $\mathrm{R}$, 10-paddock rotational). Each treatment combination was replicated twice in a completely randomized design. Animals were moved through rotationally stocked pastures based on the anticipated length of the forage regrowth period.

Grazing began when available herbage was judged to be sufficient for grazing in the spring of each season, at an approximate plant height of $15-20 \mathrm{~cm}$ (18 May 1993; 20 May 1994; 17 June 1995). Soil samples were collected 24 October 1994, 24 May 1995 and 31 July 1995. To minimize the impact of spatial variability on the estimates of soil properties, 10 soil cores $(0-10 \mathrm{~cm})$ were collected and composited into 1 sample in a plastic bag with 2 field replications. Samples were stored in a cooler and brought to the laboratory for analysis. The total number of soil samples analyzed was 24 .

Soil organic $\mathrm{C}$ was estimated using wet oxidation in dichromate and potentiometric titration (Yeomans and Bremner 1988). Total $\mathrm{N}$ was measured via dry combustion using a Leco FP-428 N analyser. Organic nitrogen was calculated as the difference between total $\mathrm{N}$ and extractable $\mathrm{NH}_{4}{ }^{+}$and $\mathrm{NO}_{3}{ }^{-}$. Water content was determined gravimetrically.

Microbial biomass $\mathrm{C}$ and $\mathrm{N}$ contents in soils were measured by chloroform fumigation and direct extraction (Voroney et al. 1993), using $25 \mathrm{~g}$ of soil, 24-hour chloroform fumigation, and a $50 \mathrm{ml} 0.5 \mathrm{M}$ $\mathrm{K}_{2} \mathrm{SO}_{4}$ extracting solution. $\mathrm{A} \mathrm{k}_{\mathrm{C}}$-factor of 0.45 was used to estimate biomass $\mathrm{C}(\mathrm{Wu}$ et. al. 1990) and a $\mathrm{k}_{\mathrm{N}}$-factor of 0.45 was used to estimate biomass N (Jenkinson 1988). Determination of dissolved organic $\mathrm{C}$ and total soluble $\mathrm{N}$ were performed on $0.5 \mathrm{M} \mathrm{K}_{2} \mathrm{SO}_{4}$ soil extracts ( $25 \mathrm{~g}$ soil: 50 $\mathrm{ml}$ extractant, 1 hour shaking) using a Technicon Autoanalyzer II (Technicon Industrial method 455-76W/A and 75984I respectively).

Nitrogen mineralization potential of soils from the 24 October 1994 samples was determined using periodic leaching of constituted soil columns (Campbell et al. 1993). Fifty grams each air dried soil and sand (soil:sand 1:1) were mixed together, placed in a leaching tube and $100 \mathrm{ml}$ of 10 $\mathrm{mM} \mathrm{CaCl} 2$ used as the leaching solution. The experiment was run for 20 weeks and leachates were collected at 2 -week intervals. The leachates were analyzed using a flow injection system analyzer for $\mathrm{NH}_{4}-\mathrm{N}$ and $\mathrm{NO}_{3}-\mathrm{N}$.

Stanford and Smith (1972) developed a model for estimation of the potentially mineralizable $\mathrm{N}\left(\mathrm{N}_{0}\right)$ of a soil and the rate of $\mathrm{N}$ mineralization $(\mathrm{k})$ by incubating the soil at optimum conditions and measuring the $\mathrm{N}$ mineralized $\left(\mathrm{N}_{\min }\right)$ and time of incubation ( $\mathrm{t}$ ), assuming that organic $\mathrm{N}$ mineralization at optimum conditions followed first-order kinetics. The following model of Stanford and Smith (1972) was used in the present study to calculate potentially mineralizable $\mathrm{N}$ and rate constant using a nonlinear regression program (SAS, Inc. 1985):

$$
\mathrm{N}_{\min }=\mathrm{N}_{0}\left(1-\mathrm{e}^{-\mathrm{kt}}\right)
$$

The content of arylsulfatase, acid phosphatase and alkaline phosphatase enzymes were assessed by measuring maximum potential activity $\left(\mathrm{V}_{\max }\right)$ using the technique of Tabatabai (1982). One gram of soil was incubated with different substrates; p-nitrophenyl sulfate ( $\mathrm{pH}$ 5.8) for arylsulfatase activity, $p$-nitrophenyl phosphate ( $\mathrm{pH}$ 6.5) for acid phosphatase activity and $p$-nitrophenyl phosphate $(\mathrm{pH} 11.0)$ for alkaline phosphatase activity. The production of $p$-nitrophenol, indicative of enzyme activity, was quantified by measuring absorbance at $400 \mathrm{~nm}$ using a spectrophotometer.

Statistical analysis of the data were performed by analysis of variance and posthoc analysis using the statistical package SuperANOVA (Abacus Concepts 1991).

\section{Results and Discussion}

\section{Soil properties}

Samples collected in fall of 1994 (20 October 1994) indicated that neither grazing system nor stocking rate had a significant effect on soil bulk density (Table 1). Soil bulk density, measured on 14 July 1995, was not significantly influenced by grazing system (continuous vs. rotational) but was significantly increased at higher stocking rates (Table 1$)$. Water content was significantly $(\mathrm{P}<0.05)$ lower in the summer sample than in the fall and spring samples, but there were no significant stocking rate or grazing system effects (Table 2). The carbon and nitrogen content of the soil organic matter were measured in the spring and summer of 1995 (Table $3)$. The only significant effect was the effect of stocking rate on organic $\mathrm{N}$ content in the continuously grazed system. Changes in the quality and quantity of soil organic matter generally occur slowly. Changes in organic matter content are difficult to quantify in short-term studies because of the changes are small relative to the large background levels of organic matter and because soil variability (Bosatta and Argen 1994). These small changes, when they can be detected, may be indicators of longer-term impacts of management system on soil quality. Quantifying relatively small changes is even more difficult in pasture systems 
Table 1. Influence of grazing system on soil bulk density measured at 3 depths in samples collected on 20 October 1994 and 14 July 1995.

\begin{tabular}{|c|c|c|c|c|}
\hline \multirow[b]{2}{*}{ System } & \multirow[b]{2}{*}{ Density } & \multirow[b]{2}{*}{ Depth } & \multicolumn{2}{|c|}{ Bulk Densities } \\
\hline & & & October 1994 & July 1995 \\
\hline Continuous & High & $\begin{array}{l}(\mathrm{cm}) \\
15 \\
30 \\
45\end{array}$ & $\begin{array}{l}-\ldots-1 \mathrm{Mg} \\
1.54 \\
1.43 \\
1.32\end{array}$ & $\begin{array}{l}-\cdots \\
1.60 \\
1.55 \\
1.55\end{array}$ \\
\hline Continuous & Low & $\begin{array}{l}15 \\
30 \\
45\end{array}$ & $\begin{array}{l}1.41 \\
1.32 \\
1.36\end{array}$ & $\begin{array}{l}1.51 \\
1.51 \\
1.51\end{array}$ \\
\hline Rotational & High & $\begin{array}{l}15 \\
30 \\
45\end{array}$ & $\begin{array}{l}1.48 \\
1.39 \\
1.34\end{array}$ & $\begin{array}{l}1.61 \\
1.63 \\
1.54\end{array}$ \\
\hline Rotational & Low & $\begin{array}{l}15 \\
30 \\
45\end{array}$ & $\begin{array}{l}1.46 \\
1.42 \\
1.43\end{array}$ & $\begin{array}{l}1.48 \\
1.51 \\
1.50\end{array}$ \\
\hline $\begin{array}{l}\text { ANOVA } \\
\text { Grazing System } \\
\text { Stocking Density } \\
\text { GS*SD } \\
\text { Depth } \\
\text { GS*Depth } \\
\text { SD*Depth } \\
\text { GS*SD*Depth }\end{array}$ & & & $\begin{array}{c}\mathrm{ns} \\
\mathrm{ns} \\
\mathrm{ns} \\
0.005 \\
\mathrm{~ns} \\
\mathrm{~ns} \\
\mathrm{~ns}\end{array}$ & $\begin{array}{c}\mathrm{ns} \\
0.001 \\
\mathrm{~ns} \\
\mathrm{~ns} \\
\mathrm{~ns} \\
\mathrm{~ns} \\
\mathrm{~ns}\end{array}$ \\
\hline
\end{tabular}

Table 2. Soil gravimentric water content as measured at the Brandon pasture study site on 3 dates.

\begin{tabular}{lllcc}
\hline \hline \multirow{2}{*}{ Sampling time } & Grazing & \multicolumn{3}{c}{ Stocking rate } \\
\cline { 3 - 5 } 24 Oct. 1994 & System & Light & Heavy & Mean \\
& Continuous & 12.4 & 9.9 & 11.2 \\
& Rotational & 11.1 & 11.7 & 11.4 \\
& Mean & 11.8 & 10.8 & $11.3 \mathrm{a}$ \\
& Continuous & 14.1 & 12.5 & 13.3 \\
& Rotational 1995 & 13.1 & 12.3 & 12.7 \\
& Mean & 13.6 & 12.4 & $13.0 \mathrm{a}$ \\
& Continuous & 9.0 & 5.7 & 7.4 \\
& Rotational 1995 & 8.0 & 9.1 & 8.6 \\
& Mean & 8.5 & 7.4 & $8.0 \mathrm{~b}$ \\
\hline
\end{tabular}

a, $b$ Means within column differ $(\mathrm{P}<0.05)$ if followed by different letter

Table 3. Influence of grazing system on soil organic carbon and nitrogen as measured on samples collected on 3 dates.

\begin{tabular}{lllccc}
\hline \hline $\begin{array}{l}\text { Sample } \\
\text { Date }\end{array}$ & $\begin{array}{l}\text { Grazing } \\
\text { System }\end{array}$ & $\begin{array}{l}\text { Stocking } \\
\text { Rate }\end{array}$ & Organic C & Organic N & C:N \\
\hline \multirow{3}{*}{ 24 May 1995 } & \multirow{3}{*}{ Continuous } & High & 16 & $1.3 \mathrm{~b}$ & 12.1 \\
& & Low & 17 & $1.7 \mathrm{a}$ & 10.3 \\
& Rotational & High & 18 & $1.5 \mathrm{ab}$ & 11.6 \\
& & Low & 20 & $1.4 \mathrm{ab}$ & 14.3 \\
& & & & & \\
31 July 1995 & Continuous & High & 16 & 1.5 & 10.7 \\
& & Low & 32 & 3.2 & 9.7 \\
& Rotational & High & 19 & 1.9 & 10.2 \\
& & Low & 19 & 1.7 & 11.0 \\
\hline
\end{tabular}

a, b Means within column differ $(\mathrm{P}<0.05)$ if followed by different letter

where there is high inherent variability in organic C contents (Herrick and Whitford 1995). The use of composite samples was intended to reduce this variation but the results presented in Table 3 reflect high variability, with differences in the mean as great as $100 \%$ not reflecting statistically significant differences. The relatively large change in soil organic $\mathrm{N}$ (Table 3 ) in the low stocking rate of the continuously grazed system may reflect variation resulting from the patchy distribution of nitrogen inputs associated with animal feces.

Sampling time had a significant $(\mathrm{P}<$ 0.001 ) effect on extractable $\mathrm{C}$ concentration (Table 4). Extractable $\mathrm{C}$ was least in summer and positively correlated with soil water content (Table 5). Ross et al. (1995) found maximum extractable $\mathrm{C}$ concentrations in early spring but reported it as a function of sieving and smearing of the soil. These differences reflect both the effects of water and animal grazing on plant growth and root exudation which is a major source of extractable carbon in soil. Differences in manure production could have also contributed to these differences. In general, significant changes were detected in the soil microbial and biochemical properties at the different sampling times. Some of these differences were related to seasons or soil water content; other environmental factors may also be involved. Spatial variability was reduced by composite sampling (Speir et al. 1984). However, spatial variability greater than that seen in cropped soils is characteristic of rangeland soils (Herrick and Whitford 1995). Temperature would have had some influence on the temporal variability of these properties. However, no attempt has been made to model or remove the influence of temperature fluctuations on biochemical activity in this study.

Extractable $\mathrm{N}$ concentration in soil did not vary among sampling periods with an overall mean value of $7.5 \mu \mathrm{g} \mathrm{N} \mathrm{g}^{-1}$ soil and individual treatment means ranging from 2.9-10.6 $\mu \mathrm{g} \mathrm{N} \mathrm{g}^{-1}$ soil. The correlation of extractable $\mathrm{N}$ with soil water content was not as strong as that of extractable C (Table 5).

\section{Microbial biomass}

Chloroform fumigation and direct extraction of freshly sampled soil was used for biomass determination in this study. Tate et al. (1991) advocated the use of fresh rather than pre-incubated soil, favoring the more versatile extraction procedure for measuring soil microbial biomass, especially for pasture soils. Banerjee and Chapman (1996) reported the range of microbial biomass $\mathrm{C}$ as $902-1485 \mu \mathrm{g} \mathrm{g}^{-1}$ soil in sandy clay loam to clay loam grassland soils. Our values for biomass $C$ (Table 6) in this study on a fine sandy loam soil were much less $\left(209-629 \mu \mathrm{g} \mathrm{g}^{-1}\right.$ soil) and similar to their values for arable soil biomass $\mathrm{C}$ range (62-795 $\mu \mathrm{g} \mathrm{g}^{-1}$ soil). Microbial biomass $\mathrm{C}$ content varied signif- 
Table 4. Extractable $\mathrm{C}$ content in soil at the Brandon pasture study site

\begin{tabular}{|c|c|c|c|c|}
\hline \multirow[b]{2}{*}{ Sampling time } & \multirow[b]{2}{*}{ Grazing system } & \multicolumn{3}{|c|}{$\ldots \ldots \ldots \ldots$ Stocking rate $\ldots \ldots \ldots$} \\
\hline & & Light & Heavy & Mean \\
\hline \multirow{4}{*}{24 Oct. 1994} & & \multicolumn{3}{|c|}{$\ldots \ldots \ldots \ldots\left(\mu g^{-1}\right.$ soil $) \ldots \ldots$} \\
\hline & Continuous & 49.8 & 48.4 & 49.1 \\
\hline & Rotational & 46.9 & 46.1 & 46.5 \\
\hline & Mean & 48.4 & 47.4 & $47.9 \mathrm{a}$ \\
\hline \multirow[t]{3}{*}{24 May 1995} & Continuous & 51.4 & 50.5 & 51.0 \\
\hline & Rotational & 48.6 & 46.4 & 47.5 \\
\hline & Mean & 50.0 & 48.5 & $49.3 \mathrm{a}$ \\
\hline \multirow[t]{3}{*}{31 July 1995} & Continuous & 11.3 & 19.3 & 15.3 \\
\hline & Rotational & 7.1 & 16.7 & 11.9 \\
\hline & Mean & 9.2 & 18.0 & $13.6 b$ \\
\hline
\end{tabular}

$\mathrm{a}$, b Means within column differ $(\mathrm{P}<0.05)$ if followed by different letter

icantly $(\mathrm{P}<0.001)$ during the year, lowest in samples taken in summer, the driest time of the year, and higher in spring (Table 6). Although biomass $\mathrm{C}$ content in fall and spring did not significantly differ, biomass $\mathrm{C}$ was correlated significantly with field water content (Table 5). Appreciable seasonal fluctuations have also been observed by DeLuca and Keeney (1994) in prairie soils. Biomass C also had a significant positive relationship with the extractable $\mathrm{C}$ in soil (Table 5).

Like other soil parameters, microbial biomass $\mathrm{C}$ was not affected by grazing system (Table 6). In contrast, stocking rate had a significant $(P<0.07)$ impact on the soil biomass $\mathrm{C}$ content, which decreased at the high stocking rate. This impact is likely the result of increased stocking intensity decreasing the photosynthetic capacity of herbage and subsequent root development (Hart and Hoveland 1989). Langlands and Bennett (1973) observed that as stocking rate increases, nutrients located in the animal pool increase and those in the plant pool decrease. They found that as stocking rate increased, herbage availability, root weight, basal cover and soil pore space declined, but soil nutrient composition appeared to be unaffected by changes in stocking rate, especially in the surface soil. Decreased photoassimilated $\mathrm{C}$ input to the root might reduce microbial growth and lower soil microbial biomass $\mathrm{C}$ (Smith and Paul 1990). Microbial biomass is the most labile pool in soil and can be a rapid indicator of any changes in the soil management system (Carter 1986, Bosatta and Argen 1994).

Biomass $\mathrm{N}$ content was significantly $(\mathrm{P}<0.001)$ affected by the time of sampling but neither grazing system nor stocking rate had any significant impact (Table 7); although soil biomass $\mathrm{N}$ tended to decrease with increasing stocking rate. Like biomass $\mathrm{C}$, biomass $\mathrm{N}$ was positively correlated with soil water content and extractable $\mathrm{C}$, but not with extractable $\mathrm{N}$ (Table 5). This suggests that extracted $\mathrm{N}$ is derived from a different pool or additional pools than that of the soil microbial biomass N (Stockdale and Rees 1994).

\section{Nitrogen mineralization}

Mineralization patterns reflect changes in substrate availability, microbial activity, and the balance between gross mineralization and immobilization. Kinetic models furnish a mathematical description of net mineralization rates (Ellert and Bettany 1988). Cumulative net mineralization rates were fit to a first-order kinetic model (Stanford and Smith 1972). Models of mineralization kinetics are the attempt to demonstrate soil biological processes, rather than pure mathematical exercises in finding the best fitting curve (Ellert and Bettany 1988). The model may oversim-

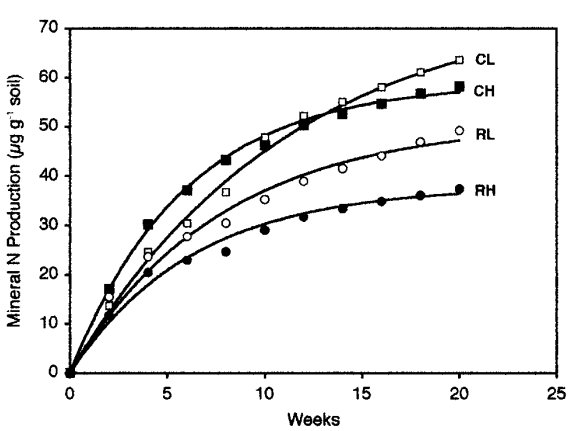

Fig. 1. Nitrogen mineralization kinetics of soils at the Brandon pasture study site. (CL $=$ Continuous grazing and Light stocking rate; $\mathbf{C H}=$ Continuous grazing and Heavy stocking rate; $\mathrm{RL}=$ Rotational grazing and Light stocking rate; $\mathbf{R H}=$ Roational grazing and Heavy stocking rate.

plify natural processes, but it should fit better than alternative models based on competing theories about the processes which produced the data set (Jowett et al. 1974). Although we did not investigate the seasonal effect on $\mathrm{N}$ mineralization potential, Ross et al. (1984) reported no evident seasonal pattern in $\mathrm{N}$ mineralization potential under grazed pasture soils of New Zealand. Our attempt was to observe whether grazing system and/or stocking rate had any effect on net mineral $\mathrm{N}$ production and rate of $\mathrm{N}$ mineralization. Net soil mineral $\mathrm{N}$ production (Fig. 1, Table 8) was higher under continuous grazing (mean $60.5 \mu \mathrm{g} \mathrm{g}^{-1}$ soil) than under rotational grazing (mean $43.0 \mu \mathrm{g} \mathrm{g}^{-1}$ soil) but, the difference was not significant $(\mathrm{P}=$ 0.34 ). Stocking rate also did not significantly affect mineral $\mathrm{N}$ production in soil. These results are consistent with Langlands and Bennet (1973) who found stocking rate did not significantly alter soil nutrient levels. Similar observations were also made in relation to effects of grazing and stocking treatments on $\mathrm{N}$ mineralization potential in soil (Fig. 1). Rates of $\mathrm{N}$ mineralization were highest during the

Table 5. Pearson's correlation coefficients between the soil parameters

\begin{tabular}{|c|c|c|c|c|c|c|c|}
\hline Parameters & Biomass $\mathrm{N}$ & Extract $\mathrm{C}$ & Extract $\mathrm{N}$ & Ary-lsulfatase & Acid Phosphatase & Al Phosp & Water \\
\hline Biomass C & $0.74 * * *$ & $0.71^{*} * *$ & -0.27 & $0.53 * *$ & $0.55 * *$ & -0.13 & $0.88 * * *$ \\
\hline Biomass N & & $0.56^{* *} *$ & -0.25 & 0.12 & 0.25 & -0.25 & $0.56^{* * *}$ \\
\hline Extract C & & & -0.31 & 0.36 & 0.17 & $0.45^{*}$ & $0.67 * * *$ \\
\hline Extract $\mathrm{N}$ & & & & -0.42 & -0.16 & 0.15 & $0.43^{*}$ \\
\hline Arylsulfatase & & & & & $0.44 *$ & 0.26 & $0.68 * * *$ \\
\hline Ac Phosp & & & & & & -0.21 & $0.68 * * *$ \\
\hline Al Phosp & & & & & & & -0.23 \\
\hline
\end{tabular}

$*, * *, * * *$ represent statistically significant at $\mathrm{p}<0.05, \mathrm{p}<0.01, \mathrm{p}<0.001$, respectively

Extract $\mathrm{C}=$ Extractable $\mathrm{C}$; Extract $\mathrm{N}=$ Extractable $\mathrm{N}$

Ac Phosp = Acid phosphatase; Al Phosp = Alkaline phosphatase 
Table 6. Soil microbial biomass $\mathrm{C}$ content at the Brandon pasture study site

\begin{tabular}{|c|c|c|c|c|}
\hline \multirow[b]{2}{*}{ Sampling time } & \multirow{2}{*}{$\begin{array}{l}\text { Grazing } \\
\text { System }\end{array}$} & \multicolumn{3}{|c|}{ Stocking rate } \\
\hline & & Light & Heavy & Mean \\
\hline \multirow{4}{*}{24 Oct. 1994} & & \multicolumn{3}{|c|}{$\ldots \ldots \ldots \ldots\left(\mathrm{g} \mathrm{C} \mathrm{g}^{-1}\right.$ soil $) \ldots \ldots$} \\
\hline & Continuous & 612 & 456 & 534 \\
\hline & Rotational & 557 & 525 & 541 \\
\hline & Mean & 585 & 491 & $538 \mathrm{a}$ \\
\hline \multirow[t]{3}{*}{24 May 1995} & Continuous & 629 & 475 & 552 \\
\hline & Rotational & 576530 & 553 & \\
\hline & Mean & 603 & 503 & $553 \mathrm{a}$ \\
\hline \multirow[t]{3}{*}{31 July 1995} & Continuous & 350 & 209 & 280 \\
\hline & Rotational & 288 & 318 & 303 \\
\hline & Mean & 319 & 264 & $292 b$ \\
\hline
\end{tabular}

a,bMeans within column differ $(\mathrm{P}<0.05)$ if followed by different letter

Table 7. Soil microbial biomass $\mathbf{N}$ content at the Brandon study site

\begin{tabular}{|c|c|c|c|c|}
\hline \multirow[b]{2}{*}{ Sampling time } & \multirow{2}{*}{$\begin{array}{l}\text { Grazing } \\
\text { System }\end{array}$} & \multicolumn{3}{|c|}{ Stocking rate } \\
\hline & & Light & Heavy & $\overline{\text { Mean }}$ \\
\hline \multirow{4}{*}{24 Oct. 1994} & & $\ldots$ & $\mathrm{g} \mathrm{g} \mathrm{g}^{-1}$ & $\ldots$ \\
\hline & Continuous & 63.8 & 66.2 & 65.0 \\
\hline & Rotational & 99.6 & 67.8 & 83.7 \\
\hline & Mean & 81.6 & 67.0 & $74.3 \mathrm{a}$ \\
\hline 24 May 1995 & Continuous & 70.7 & 52.1 & 61.4 \\
\hline \multirow{5}{*}{31 July 1995} & Rotational & 51.1 & 38.3 & 44.7 \\
\hline & Mean & 60.9 & 45.2 & $53.1 \mathrm{a}$ \\
\hline & Continuous & 28.2 & 19.3 & 23.8 \\
\hline & Rotational & 15.7 & 27.2 & 21.5 \\
\hline & Mean & 22.0 & 23.3 & $22.7 b$ \\
\hline
\end{tabular}

a,bMeans within column differ $(\mathrm{P}<0.05)$ if followed by different letter

Table 8. Kinetic description of $\mathbf{N}$ mineralization rate of soils collected from the Brandon Pasture study.

\begin{tabular}{|c|c|c|c|c|c|c|}
\hline Grazing System & Stocking Rate & $\mathrm{N}_{\min }$ & $\mathrm{N}_{\mathrm{O}}$ & $\mathrm{k}$ & Regression Equation & $\begin{array}{l}\text { Coefficient of } \\
\text { Determination }\end{array}$ \\
\hline & & $\left(\mu \mathrm{g} \mathrm{g}^{-1}\right)$ & \multicolumn{2}{|c|}{$\left(\mu \mathrm{g} \mathrm{g}^{-1}\right)\left(w^{-1}\right)$} & & \\
\hline Continuous & Light & 63 & 76 & 0.09 & $\mathrm{~N}_{\min }=76\left(1-\mathrm{e}^{-0.09 \mathrm{t}}\right)$ & 0.99 \\
\hline Continuous & Heavy & 58 & 59 & 0.17 & $\mathrm{~N}_{\min }=59\left(1-\mathrm{e}^{0.17 \mathrm{t}}\right)$ & 0.99 \\
\hline Rotational & Light & 49 & 51 & 0.13 & $\mathrm{~N}_{\min }=51\left(1-\mathrm{e}^{0.13 \mathrm{t}}\right)$ & 0.98 \\
\hline Rotational & Heavy & 37 & 38 & 0.16 & $\mathrm{~N}_{\min }=38\left(1-\mathrm{e}^{0.16 \mathrm{t}}\right)$ & 0.99 \\
\hline
\end{tabular}

Table 9. Arylsulfatase activity in soil at the Brandon pasture study site

\begin{tabular}{|c|c|c|c|c|}
\hline \multirow[b]{2}{*}{ Sampling time } & \multirow{2}{*}{$\begin{array}{l}\text { Grazing } \\
\text { System }\end{array}$} & \multicolumn{3}{|c|}{ Stocking rate } \\
\hline & & Light & Heavy & Mean \\
\hline 24 Oct. 1994 & $\begin{array}{l}\text { Continuous } \\
\text { Rotational } \\
\text { Mean }\end{array}$ & $\begin{array}{l}---- \\
42.8 \\
47.7 \\
45.4\end{array}$ & $\begin{array}{l}\text { nitrophe } \\
31.9 \\
51.9 \\
41.9\end{array}$ & $\begin{array}{l}37.4 \\
49.8 \\
43.7 \mathrm{a}\end{array}$ \\
\hline 24 May 1995 & $\begin{array}{l}\text { Continuous } \\
\text { Rotational } \\
\text { Mean }\end{array}$ & $\begin{array}{l}90.5 \\
89.1 \\
89.8\end{array}$ & $\begin{array}{l}72.5 \\
69.4 \\
71.0\end{array}$ & $\begin{array}{l}81.5 \\
79.3 \\
80.4 \mathrm{~b}\end{array}$ \\
\hline 31 July 1995 & $\begin{array}{l}\text { Continuous } \\
\text { Rotational } \\
\text { Mean }\end{array}$ & $\begin{array}{l}44.4 \\
44.1 \\
44.3\end{array}$ & $\begin{array}{l}43.4 \\
58.7 \\
51.1\end{array}$ & $\begin{array}{l}43.9 \\
51.4 \\
47.7 \mathrm{a}\end{array}$ \\
\hline
\end{tabular}

a, b Means within column differ $(\mathrm{P}<0.05)$ if followed by different letter

first 2 weeks of incubation and decreased with time as the labile organic $\mathrm{N}$ was depleted. The cumulative mineral $\mathrm{N}$ produced was usually lower than the estimated potential mineralizable $\mathrm{N}$ after 20 weeks of incubation, indicating some of the organic $\mathrm{N}$ fraction was still available for further mineralization (Table 8). The values of the rate constant $(\mathrm{k})$ range from 0.09 to $0.17 \mathrm{wk}^{-1}$ under continuous grazing (mean $0.13 \mathrm{wk}^{-1}$ ) and 0.13 to $0.16 \mathrm{wk}-1$ under rotational grazing system (mean $\left.0.145 \mathrm{wk}^{-1}\right)$

\section{Enzyme activities}

Both arylsulfatase and alkaline phosphatase activities showed significant $(\mathrm{P}<$ 0.05 ) differences between sampling times, but did not show similar times of minimum and maximum activity (Tables 9 and 10). Arylsulfatase activity was highest during spring and alkaline phosphatase activity was highest during summer, but acid phosphatase activity was not significantly affected by sampling time (Table 11). In contrast, Ross et al. (1995) reported non-significant seasonal fluctuations of arylsulfatase activity but very marked seasonal fluctuations of phosphatase activity in their soils. Seasonal variation in soil enzyme activities have been shown by Ladd (1978) as well. As found here, fluctuations in enzyme activity have not always coincided with season, and are often difficult to interpret. In our study, grazing systems and stocking rates did not significantly impact arylsulfatase (Table 9) and alkaline phosphatase activities (Table 10) but acid phosphatase activity was significantly $(\mathrm{P}<0.03)$ decreased under heavy stocking compared to light stocking (Table 11). Grazing system had no significant effect on the acid phosphatase activity. Arylsulfatase and acid phosphatase activities were correlated significantly and positively with soil water and biomass $\mathrm{C}$ (Table 5), whereas alkaline phosphatase activity had no significant relationship with soil water and biomass C. Soil enzymes are probably derived to a considerable extent from soil microorganisms (Ladd 1978). In this study arylsulfatase and acid phosphatase were correlated with microbial biomass $\mathrm{C}$ but alkaline phosphatase was not (Table 5).

Overall, at this site seasonal fluctuations occurred in the microbial and biochemical properties reported here. In general, these fluctuations were mainly independent of the variations in soil organic matter content (Ross et al. 1984) but were more closely related to soil water content. Of the parameters examined here, $\mathrm{N}$ mineralization is perhaps the most useful in assessing the productivity of the site as it is primarily an assessment availability and quality ( $\mathrm{C}: \mathrm{N}$ ratio) of mineralizable substrates. Mineralizable N was lower under rotational than under continuous grazing. Measures of biomass $\mathrm{C}$ and $\mathrm{N}$ represent both the catalytic potential of the soil and a measure of substrate availability. The initial data does suggest increased stock- 
Table 10. Alkaline phosphatase activity in soil at the Brandon pasture study site

\begin{tabular}{|c|c|c|c|c|}
\hline \multirow[b]{2}{*}{ Sampling time } & \multirow{2}{*}{$\begin{array}{l}\text { Grazing } \\
\text { System }\end{array}$} & \multicolumn{3}{|c|}{ Stocking rate } \\
\hline & & Light & Heavy & Mean \\
\hline 24 Oct. 1994 & $\begin{array}{l}\text { Continuous } \\
\text { Rotational } \\
\text { Mean }\end{array}$ & $\begin{array}{l}---\cdot \\
152.9 \\
145.7 \\
149.3\end{array}$ & $\begin{array}{l}\text { itrophen } \\
128.4 \\
155.7 \\
142.1\end{array}$ & $\begin{array}{l}140.7 \\
140.7 \\
150.7 \\
145.7 \mathrm{a}\end{array}$ \\
\hline 24 May 1995 & $\begin{array}{l}\text { Continuous } \\
\text { Rotational } \\
\text { Mean }\end{array}$ & $\begin{array}{l}179.5 \\
156.5 \\
168.0\end{array}$ & $\begin{array}{l}142.2 \\
166.4 \\
154.3\end{array}$ & $\begin{array}{l}160.9 \\
161.5 \\
161.2 \mathrm{a}\end{array}$ \\
\hline 31 July 1995 & $\begin{array}{l}\text { Continuous } \\
\text { Rotational } \\
\text { Mean }\end{array}$ & $\begin{array}{l}175.5 \\
172.0 \\
173.7\end{array}$ & $\begin{array}{l}196.3 \\
198.2 \\
197.2\end{array}$ & $\begin{array}{l}185.9 \\
185.1 \\
185.5 b\end{array}$ \\
\hline
\end{tabular}

a, b Means within column differ $(\mathrm{P}<0.05)$ if followed by different letter

Table 11. Acid phosphatase activity in soil at the Brandon pasture study site

\begin{tabular}{|c|c|c|c|c|}
\hline \multirow[b]{2}{*}{ Sampling time } & \multirow{2}{*}{$\begin{array}{l}\text { Grazing } \\
\text { System }\end{array}$} & \multicolumn{3}{|c|}{ Stocking rate } \\
\hline & & Light & Heavy & Mean \\
\hline 24 Oct. 1994 & $\begin{array}{l}\text { Continuous } \\
\text { Rotational } \\
\text { Mean }\end{array}$ & $\begin{array}{l}-\ldots-- \\
190.1 \\
181.2 \\
185.6 \mathrm{a}\end{array}$ & $\begin{array}{l}\text { hitrophen } \\
171.1 \\
183.6 \\
177.4 \mathrm{~b}\end{array}$ & $\begin{array}{l}-180.6 \\
180.6 \\
182.4 \\
181.5\end{array}$ \\
\hline 24 May 1995 & $\begin{array}{l}\text { Continuous } \\
\text { Rotational } \\
\text { Mean }\end{array}$ & $\begin{array}{l}225.8 \\
212.4 \\
219.2 \mathrm{a}\end{array}$ & $\begin{array}{l}173.0 \\
170.8 \\
171.8 \mathrm{~b}\end{array}$ & $\begin{array}{l}199.4 \\
191.6 \\
195.5\end{array}$ \\
\hline 31 July 1995 & $\begin{array}{l}\text { Continuous } \\
\text { Rotational } \\
\text { Mean }\end{array}$ & $\begin{array}{l}200.0 \\
169.6 \\
184.8 \mathrm{a}\end{array}$ & $\begin{array}{l}92.4 \\
195.6 \\
144.0 \mathrm{~b}\end{array}$ & $\begin{array}{l}146.2 \\
182.6 \\
164.4\end{array}$ \\
\hline
\end{tabular}

a, b Means within row differ $(\mathrm{P}<0.05)$ if followed by different letter

ing rate decreases soil microbial biomass $\mathrm{C}$, mineralizable $\mathrm{N}$, and acid phosphatase activity. The measures of enzyme content are more difficult to interpret as they indicate potential enzyme activity under conditions of excess substrate. Enzyme activity in soil systems is often primarily limited by substrate availability (Burton and McGill 1991). Due to the limited duration of the investigation, limited number of replications, and high soil variability encountered in this study, it may not be advisable to recommend any particular grazing system and/or stocking rate favorable for the maintenance of soil biological quality. The high degree of variation observed might be anticipated in view of the distribution of nitrogen rich feces and urine in pasture systems. Longer-term investigation involving more frequent sampling with increased replication is needed to assess more completely the impact of grazing system or stocking rate on soil biological characteristics. However, these preliminary results indicate possible adverse effects of excessively high stocking on soil health or quality.

\section{Literature Cited}

Abacus Concepts. 1991. SuperAnova Users Guide. Version 1.11, Abacus Concepts, Berkeley, Calif.

Banerjee, M. R. and S.J. Chapman. 1996. The significance of microbial biomass sulfur in soil. Biol. Fertil. Soils. 22:116-125.

Bosatta, E. and G.I. Agren. 1994. Theoretical analysis of microbial biomass dynamics in soils. Soil Biol. Biochem. 26:143-148.

Burton, D.L. and W.B. McGill. 1991. Inductive and repressive effects of carbon and nitrogen on L-histidine ammonia-lyase activity in a black chernozemic soil. Soil Biol. Biochem. 23:939-946.

Campbell, C.A., B.H. Ellert, and Y.W. Jame. 1993. Nitrogen mineralization potential in soils. pp. 341-349. In: M.R. Carter (ed.) Soil Sampling and Methods of Analysis. Lewis Publishers, Ann Arbour, Mich.

Carter, M.R., 1986. Microbial biomass as an index for tillage-induced changes in soil biological properties. Soil and Tillage Res. 7: 29-40.

DeLuca, T.H. and D.R. Keeney. 1994. Soluble carbon and nitrogen pools of prairie and cultivated soils: seasonal variation. Soil Sci. Soc. Amer. J. 58:835-840.
Doran, J.W. and T.B. Parkin. 1994. Defining and assessing soil quality. pp. 3-21. In: J.W. Doran, D.C. Coleman, D.F. Bezdicek, and B.A. Stewart (eds.) Defining Soil Quality for a Sustainable Environment. Soil Sci. Soc. Amer. Special Publ. No. 35, Soil Sci. Soc. of America Inc., Madison, Wisc.

Ehrlich, W.A., E.A. Poywer, and L.E. Pratt. 1957. Report of reconnaissance soil survey of Carberry map sheet area. Soils Report No.7 Manitoba Dept. of Agr. and Immigration, $93 \mathrm{pp}$.

Ellert, B.H. and J.R. Bettany. 1988. Comparison of kinetic models for describing net sulfur and nitrogen mineralization. Soil Sci. Soc. Amer. J. 52:1692-1702.

Hart, R.H. and C.S. Hoveland. 1989. Objectives of grazing trials. pp. 1-5 In: G. C. Marten (ed.) Grazing Research: Design, Methodology, and Analysis. CSSA Special Publication No. 16, Madison, Wisc.

Herrick, J.E. and W.G. Whitford. 1995. Assessing the quality of rangeland soils: Challenges and opportunities. J. Soil Water Conser. 50:237-242.

Howarth, R.E. and B.P. Golpen. 1983 Improvement of forage quality through production management and plant breeding. Can. J. Plant Sci., 63, 895-902.

Jenkinson, D.S., 1988, Determination of microbial biomass carbon and nitrogen in soil. pp. 368-386. In: J.R. Wilson (ed.) Advances in nitrogen cycling in agricultural ecosystems. CAB, Wallingford.

Jowett, D., J.A. Browning, and B.C. Haning. 1974. Non-linear disease progress curves. pp. 115-136. In: J. Kranz (ed.) Epidemics of plant diseases-mathematical analysis and modelling. Springer-Verlag, New York, N.Y.

Jung, H.G., R.W. Rice, and L.J. Koong. 1985. Comparison of heifer weight gains and forage quality for continuous and short duration grazing systems. J. Range Manage. 38: 144-148.

Ladd, J.N. 1978. Origin and range of enzymes in soil. pp. 51-96. In: R.G. Burns (ed.) Soil Enzymes, Academic Press, London.

Langlands, J.P. and I.L. Bennett. 1973. Stocking intensity and pastoral production I. Changes in the soil and vegetation of a sown pasture grazed by sheep at different stocking rates. J. Agr. Sci., Camb. 81:193-204.

Magdoff, F. 1995. Soil quality and management. pp. 349-364. In: M.A. Altieri (ed.) Agroecology: The Science of Sustainable Agriculture, 2nd Edition., Westview Press, Boulder, Colo.

Ross, D.J., T.W. Speir, J.C. Cowling, and K.N. Whale. 1984. Temporal fluctuations in biochemical properties of soil under pasture. II. Nitrogen mineralization and enzyme activities. Aust. J. Soil Res. 22:319-330.

Ross, D.J., T.W. Speir, H.A. Kettles, and A.D. Mackay. 1995. Soil microbial biomass, $\mathrm{C}$ and $\mathrm{N}$ mineralization and enzyme activities in a hill pasture: influence of season and slow-release P and S fertilizer. Soil Biol. Biochem. 27:1431-1443. 


\title{
Influence of pasture management on soil biological quality
}

\author{
MANAS R. BANERJEE, DAVID L. BURTON, W. P. (PAUL) MCCAUGHEY, AND C.A. GRANT
}

Authors are post doctoral research associate and associate professor Department of Soil Science, University of Manitoba, Winnipeg, Manitoba, Canada R3T 2N2; and scientists at Agriculture and Agri-Food Canada, Research Centre, Brandon, Manitoba, Canada R7A 5Y3

\begin{abstract}
The long-term sustainability of pasture management systems, whether related to structural stability or nutrient dynamics, is dependent upon maintaining soil biological properties. This study investigates the extent to which the microbiological and biochemical properties of soil can change with season and pasture management system, including their likely value as indicators of soil quality. The experiment was conducted on a 30-ha pasture near Brandon, Manitoba. Seasonal fluctuations were observed in the soil microbial and biochemical properties. In general, these fluctuations were mainly independent of the small variations in soil organic matter content but were more closely related to soil water content. The data also suggests an impact of stocking rate and grazing system on soil microbial biomass $\mathrm{C}$ and on $\mathbf{N}$ mineralization potential. However, because duration of the investigation, limited number of replications and the high soil variability encountered, it is not yet possible to recommend any particular grazing system and/or stocking rate favorable for the maintenance of soil biological quality. The trends suggest that light, continuous grazing systems had the largest microbial biomass and nutrient mineralizing activity.
\end{abstract}

Key Words: Microbial biomass carbon, soil enzyme activity, grazing system, stocking rate, rotational grazing

The grazing of pasture and range lands by livestock is common practice in Canada and elsewhere and grazing management systems have been shown to influence the soil-plant ecosystem (Warren et al. 1986). The duration and intensity of grazing may affect conservation of soil, water and biological organisms. It has been suggested that the inclusion of a livestock component might play a significant role in increasing the long-term sustainability of agricultural ecosystems (Magdoff 1995). According to Hart and Hoveland (1989) grazing livestock exert 4 primary effects on pasture: a) Defoliation of herbage reduces photosynthetic capacity and may reduce root development, carbohydrate storage, and $\mathrm{N}_{2}$ fixation. b) Selectivity for plant parts and plant species in a mixed stand may affect relative productivity and persistence of the species present and invasion of undesirable species. c) Trampling damages plant tissue, increases soil bulk density, and slows water infiltration. d) Excretion concentrates urine and dung in small areas and affects plant palatability and nutrient cycling.

Grazing systems may contribute to maintaining high forage nutritional value on pastures (Howarth and Goplen 1983). The quality of forage sustained in rotationally stocked pastures has

Accepted 11 Mar. 1999

\section{Resumen}

La sustentabilidad a largo plazo de los sistemas de manejo de potreros, ya sea relacionados a la estabilidad estructural o la dinámica de nutrientes, depende de mantener las propiedades biológicas del suelo. Este estudio investigo la cantidad a la que las propiedades microbiológicas y bioquímicas del suelo pueden cambiar con la estación y el manejo del potrero, incluyendo su valor probable como indicadores de la calidad del suelo. El experimento se condujo en un potrero de 30 ha cerca de Brandon, Manitoba. Se observaron las fluctuaciones estacionales de las propiedades microbianas y bioquímicas del suelo. En general, estas fluctuaciones fueron principalmente independientes de las pequeñas variaciones del contenido de materia orgánica, pero estuvieron muy relacionadas al contenido de agua del suelo. Los datos también sugieren un impacto de la carga animal y del sistema de apacentamiento en la biomasa microbiana y el potencial de mineralización de carbón y nitrógeno. Sin embargo, debido a la duración de la investigación, el limitado número de repeticiones y la alta variabilidad encontrada, no es posible recomendar un sistema de apacentamiento y/o una carga animal favorable para mantener la calidad biológica del suelo. Las tendencias sugieren que una carga ligera con el sistemas de apacentamiento continuo tuvo la mayor biomasa microbiana y la mayor actividad mineralizante de nutrientes.

been reported to be greater than that in pastures stocked continuously (Walton et. al. 1981), but in both rotational and continuous systems, seasonal fluctuations in forage quality have been noted (Jung et al. 1985). Sharrow (1983) demonstrated that better nutrition is provided to animals in rotationally than continuously stocked paddocks, because amounts of plant biomass are greater. Grazing system and stocking intensity experiments in pasture research have focused on livestock weight gains, and forage quality and quantity (Langlands and Bennett 1973, Walton et al. 1981, Jung et al. 1985). However, the nutritional quality and quantity of forages in pasture also depend on the quality of the soil in which they grow. The maintenance and improvement of soil quality is fundamental to sustaining soil fertility and productivity. Soil microbial and biochemical properties are related to soil fertility and productivity. The extent to which these properties can change with season or pasture management system is of interest from several viewpoints, including their likely value as indicators of soil quality (Doran and Parkin 1994). Thus, livestock grazing and stocking rate might affect soil microbial activities and their role in nutrient transformation in pasture land. Our object was to determine the effects of grazing system (including stocking rate) and season on microbial and biochemical properties of soil. 
The soil biota is the main driving force behind nutrient and energy transformations in soil. Through the production of enzymes, soil organisms mediate the major catalytic processes in soil as well as being themselves substrates for decomposition. The microbial community inhabits the soil environment, responding to physical, chemical or biological perturbation. Soil biological properties were chosen to represent the soil environment in which organisms must exist (soil organic matter content, water content), the microbial community itself (microbial biomass $\mathrm{C}$ and $\mathrm{N}$ content) and biochemical activity of the microbial population ( $\mathrm{N}$ mineralization, arylsulfatase and phosphatase). The biochemical activities were chosen to be representative of the major nutrients $(\mathrm{N}, \mathrm{P}$ and $\mathrm{S}$ ) which influence plant productivity. In this work we evaluate the magnitude and change in these properties, albeit over a limited time frame, and interpret these findings in the context of soil quality and productivity.

\section{Materials and Methods}

The experiment was conducted on a 30ha pasture near Brandon, Manitoba (49 ${ }^{\circ}$ $52^{\prime} \mathrm{N}$; $99^{\circ}$ 59' W; Elevation $363 \mathrm{~m}$ above sea level). Initially, the pasture consisted of approximately $70 \%$ alfalfa (Medicago sativa L.), $25 \%$ meadow bromegrass (Bromus biebersteinii Roem and Schult.) and 5\% Russian wildrye (Psathyrostachys juncea (Fisch.) Nevski). The area was seeded in 1990 and pastures were fertilized with N, P, K, and S to meet Manitoba provincial soil test recommended levels. The site was located on an Orthic Black Chernozem soil rated as class 5 Souris fine sandy loam soil (Ehrlich et al. 1957) Analysis for plant macronutrients was conducted by NorWest labs and indicated the following results: $\mathrm{N}, 14.0 \mathrm{~kg} \mathrm{ha}^{-1}$ $\left(\mathrm{CaCl} 2\right.$ extract); $\mathrm{P}, 40.1 \mathrm{~kg} \mathrm{h \textrm {h } ^ { - 1 }}$ $\left(\mathrm{NH}_{4} \mathrm{C}_{2} \mathrm{H}_{3} \mathrm{O}_{2} / \mathrm{CH}_{3} \mathrm{COF}\right.$ extract); K, 256.4 $\mathrm{kg} \mathrm{ha}^{-1}\left(\mathrm{NH}_{4} \mathrm{C}_{2} \mathrm{H}_{3} \mathrm{O}_{2} / \mathrm{CH}_{3} \mathrm{COF}\right.$ extract); and $\mathrm{S}, 21.1 \mathrm{~kg} \mathrm{ha}^{-1}\left(\mathrm{CaCl}_{2}\right.$ extract). The area was subdivided into eight, 3.7-ha pastures, which were allocated to a factorial combination of treatments, consisting of 2 stocking rates $(\mathrm{H}$, heavy; 8 steers per pasture, or 2.2 steers $\mathrm{ha}^{-1}$; and L, light; 4 steers per pasture, or 1.1 steers ha $\left.{ }^{-1}\right)$ and 2 grazing intensities $(\mathrm{C}$, continuous and $\mathrm{R}$, 10-paddock rotational). Each treatment combination was replicated twice in a completely randomized design. Animals were moved through rotationally stocked pastures based on the anticipated length of the forage regrowth period.

Grazing began when available herbage was judged to be sufficient for grazing in the spring of each season, at an approximate plant height of $15-20 \mathrm{~cm}$ (18 May 1993; 20 May 1994; 17 June 1995). Soil samples were collected 24 October 1994, 24 May 1995 and 31 July 1995. To minimize the impact of spatial variability on the estimates of soil properties, 10 soil cores $(0-10 \mathrm{~cm})$ were collected and composited into 1 sample in a plastic bag with 2 field replications. Samples were stored in a cooler and brought to the laboratory for analysis. The total number of soil samples analyzed was 24 .

Soil organic $\mathrm{C}$ was estimated using wet oxidation in dichromate and potentiometric titration (Yeomans and Bremner 1988). Total $\mathrm{N}$ was measured via dry combustion using a Leco FP-428 N analyser. Organic nitrogen was calculated as the difference between total $\mathrm{N}$ and extractable $\mathrm{NH}_{4}{ }^{+}$and $\mathrm{NO}_{3}{ }^{-}$. Water content was determined gravimetrically.

Microbial biomass $\mathrm{C}$ and $\mathrm{N}$ contents in soils were measured by chloroform fumigation and direct extraction (Voroney et al. 1993), using $25 \mathrm{~g}$ of soil, 24-hour chloroform fumigation, and a $50 \mathrm{ml} 0.5 \mathrm{M}$ $\mathrm{K}_{2} \mathrm{SO}_{4}$ extracting solution. $\mathrm{A} \mathrm{k}_{\mathrm{C}}$-factor of 0.45 was used to estimate biomass $\mathrm{C}(\mathrm{Wu}$ et. al. 1990) and a $\mathrm{k}_{\mathrm{N}}$-factor of 0.45 was used to estimate biomass N (Jenkinson 1988). Determination of dissolved organic $\mathrm{C}$ and total soluble $\mathrm{N}$ were performed on $0.5 \mathrm{M} \mathrm{K}_{2} \mathrm{SO}_{4}$ soil extracts ( $25 \mathrm{~g}$ soil: 50 $\mathrm{ml}$ extractant, 1 hour shaking) using a Technicon Autoanalyzer II (Technicon Industrial method 455-76W/A and 75984I respectively).

Nitrogen mineralization potential of soils from the 24 October 1994 samples was determined using periodic leaching of constituted soil columns (Campbell et al. 1993). Fifty grams each air dried soil and sand (soil:sand 1:1) were mixed together, placed in a leaching tube and $100 \mathrm{ml}$ of 10 $\mathrm{mM} \mathrm{CaCl} 2$ used as the leaching solution. The experiment was run for 20 weeks and leachates were collected at 2 -week intervals. The leachates were analyzed using a flow injection system analyzer for $\mathrm{NH}_{4}-\mathrm{N}$ and $\mathrm{NO}_{3}-\mathrm{N}$.

Stanford and Smith (1972) developed a model for estimation of the potentially mineralizable $\mathrm{N}\left(\mathrm{N}_{0}\right)$ of a soil and the rate of $\mathrm{N}$ mineralization $(\mathrm{k})$ by incubating the soil at optimum conditions and measuring the $\mathrm{N}$ mineralized $\left(\mathrm{N}_{\min }\right)$ and time of incubation ( $\mathrm{t}$ ), assuming that organic $\mathrm{N}$ mineralization at optimum conditions followed first-order kinetics. The following model of Stanford and Smith (1972) was used in the present study to calculate potentially mineralizable $\mathrm{N}$ and rate constant using a nonlinear regression program (SAS, Inc. 1985):

$$
\mathrm{N}_{\min }=\mathrm{N}_{0}\left(1-\mathrm{e}^{-\mathrm{kt}}\right)
$$

The content of arylsulfatase, acid phosphatase and alkaline phosphatase enzymes were assessed by measuring maximum potential activity $\left(\mathrm{V}_{\max }\right)$ using the technique of Tabatabai (1982). One gram of soil was incubated with different substrates; p-nitrophenyl sulfate ( $\mathrm{pH}$ 5.8) for arylsulfatase activity, $p$-nitrophenyl phosphate ( $\mathrm{pH}$ 6.5) for acid phosphatase activity and $p$-nitrophenyl phosphate $(\mathrm{pH} 11.0)$ for alkaline phosphatase activity. The production of $p$-nitrophenol, indicative of enzyme activity, was quantified by measuring absorbance at $400 \mathrm{~nm}$ using a spectrophotometer.

Statistical analysis of the data were performed by analysis of variance and posthoc analysis using the statistical package SuperANOVA (Abacus Concepts 1991).

\section{Results and Discussion}

\section{Soil properties}

Samples collected in fall of 1994 (20 October 1994) indicated that neither grazing system nor stocking rate had a significant effect on soil bulk density (Table 1). Soil bulk density, measured on 14 July 1995, was not significantly influenced by grazing system (continuous vs. rotational) but was significantly increased at higher stocking rates (Table 1$)$. Water content was significantly $(\mathrm{P}<0.05)$ lower in the summer sample than in the fall and spring samples, but there were no significant stocking rate or grazing system effects (Table 2). The carbon and nitrogen content of the soil organic matter were measured in the spring and summer of 1995 (Table $3)$. The only significant effect was the effect of stocking rate on organic $\mathrm{N}$ content in the continuously grazed system. Changes in the quality and quantity of soil organic matter generally occur slowly. Changes in organic matter content are difficult to quantify in short-term studies because of the changes are small relative to the large background levels of organic matter and because soil variability (Bosatta and Argen 1994). These small changes, when they can be detected, may be indicators of longer-term impacts of management system on soil quality. Quantifying relatively small changes is even more difficult in pasture systems 
Table 1. Influence of grazing system on soil bulk density measured at 3 depths in samples collected on 20 October 1994 and 14 July 1995.

\begin{tabular}{|c|c|c|c|c|}
\hline \multirow[b]{2}{*}{ System } & \multirow[b]{2}{*}{ Density } & \multirow[b]{2}{*}{ Depth } & \multicolumn{2}{|c|}{ Bulk Densities } \\
\hline & & & October 1994 & July 1995 \\
\hline Continuous & High & $\begin{array}{l}(\mathrm{cm}) \\
15 \\
30 \\
45\end{array}$ & $\begin{array}{l}-\ldots-1 \mathrm{Mg} \\
1.54 \\
1.43 \\
1.32\end{array}$ & $\begin{array}{l}-\cdots \\
1.60 \\
1.55 \\
1.55\end{array}$ \\
\hline Continuous & Low & $\begin{array}{l}15 \\
30 \\
45\end{array}$ & $\begin{array}{l}1.41 \\
1.32 \\
1.36\end{array}$ & $\begin{array}{l}1.51 \\
1.51 \\
1.51\end{array}$ \\
\hline Rotational & High & $\begin{array}{l}15 \\
30 \\
45\end{array}$ & $\begin{array}{l}1.48 \\
1.39 \\
1.34\end{array}$ & $\begin{array}{l}1.61 \\
1.63 \\
1.54\end{array}$ \\
\hline Rotational & Low & $\begin{array}{l}15 \\
30 \\
45\end{array}$ & $\begin{array}{l}1.46 \\
1.42 \\
1.43\end{array}$ & $\begin{array}{l}1.48 \\
1.51 \\
1.50\end{array}$ \\
\hline $\begin{array}{l}\text { ANOVA } \\
\text { Grazing System } \\
\text { Stocking Density } \\
\text { GS*SD } \\
\text { Depth } \\
\text { GS*Depth } \\
\text { SD*Depth } \\
\text { GS*SD*Depth }\end{array}$ & & & $\begin{array}{c}\mathrm{ns} \\
\mathrm{ns} \\
\mathrm{ns} \\
0.005 \\
\mathrm{~ns} \\
\mathrm{~ns} \\
\mathrm{~ns}\end{array}$ & $\begin{array}{c}\mathrm{ns} \\
0.001 \\
\mathrm{~ns} \\
\mathrm{~ns} \\
\mathrm{~ns} \\
\mathrm{~ns} \\
\mathrm{~ns}\end{array}$ \\
\hline
\end{tabular}

Table 2. Soil gravimentric water content as measured at the Brandon pasture study site on 3 dates.

\begin{tabular}{lllcc}
\hline \hline \multirow{2}{*}{ Sampling time } & Grazing & \multicolumn{3}{c}{ Stocking rate } \\
\cline { 3 - 5 } 24 Oct. 1994 & System & Light & Heavy & Mean \\
& Continuous & 12.4 & 9.9 & 11.2 \\
& Rotational & 11.1 & 11.7 & 11.4 \\
& Mean & 11.8 & 10.8 & $11.3 \mathrm{a}$ \\
& Continuous & 14.1 & 12.5 & 13.3 \\
& Rotational 1995 & 13.1 & 12.3 & 12.7 \\
& Mean & 13.6 & 12.4 & $13.0 \mathrm{a}$ \\
& Continuous & 9.0 & 5.7 & 7.4 \\
& Rotational 1995 & 8.0 & 9.1 & 8.6 \\
& Mean & 8.5 & 7.4 & $8.0 \mathrm{~b}$ \\
\hline
\end{tabular}

a, $b$ Means within column differ $(\mathrm{P}<0.05)$ if followed by different letter

Table 3. Influence of grazing system on soil organic carbon and nitrogen as measured on samples collected on 3 dates.

\begin{tabular}{lllccc}
\hline \hline $\begin{array}{l}\text { Sample } \\
\text { Date }\end{array}$ & $\begin{array}{l}\text { Grazing } \\
\text { System }\end{array}$ & $\begin{array}{l}\text { Stocking } \\
\text { Rate }\end{array}$ & Organic C & Organic N & C:N \\
\hline \multirow{3}{*}{ 24 May 1995 } & \multirow{3}{*}{ Continuous } & High & 16 & $1.3 \mathrm{~b}$ & 12.1 \\
& & Low & 17 & $1.7 \mathrm{a}$ & 10.3 \\
& Rotational & High & 18 & $1.5 \mathrm{ab}$ & 11.6 \\
& & Low & 20 & $1.4 \mathrm{ab}$ & 14.3 \\
& & & & & \\
31 July 1995 & Continuous & High & 16 & 1.5 & 10.7 \\
& & Low & 32 & 3.2 & 9.7 \\
& Rotational & High & 19 & 1.9 & 10.2 \\
& & Low & 19 & 1.7 & 11.0 \\
\hline
\end{tabular}

a, b Means within column differ $(\mathrm{P}<0.05)$ if followed by different letter

where there is high inherent variability in organic C contents (Herrick and Whitford 1995). The use of composite samples was intended to reduce this variation but the results presented in Table 3 reflect high variability, with differences in the mean as great as $100 \%$ not reflecting statistically significant differences. The relatively large change in soil organic $\mathrm{N}$ (Table 3 ) in the low stocking rate of the continuously grazed system may reflect variation resulting from the patchy distribution of nitrogen inputs associated with animal feces.

Sampling time had a significant $(\mathrm{P}<$ 0.001 ) effect on extractable $\mathrm{C}$ concentration (Table 4). Extractable $\mathrm{C}$ was least in summer and positively correlated with soil water content (Table 5). Ross et al. (1995) found maximum extractable $\mathrm{C}$ concentrations in early spring but reported it as a function of sieving and smearing of the soil. These differences reflect both the effects of water and animal grazing on plant growth and root exudation which is a major source of extractable carbon in soil. Differences in manure production could have also contributed to these differences. In general, significant changes were detected in the soil microbial and biochemical properties at the different sampling times. Some of these differences were related to seasons or soil water content; other environmental factors may also be involved. Spatial variability was reduced by composite sampling (Speir et al. 1984). However, spatial variability greater than that seen in cropped soils is characteristic of rangeland soils (Herrick and Whitford 1995). Temperature would have had some influence on the temporal variability of these properties. However, no attempt has been made to model or remove the influence of temperature fluctuations on biochemical activity in this study.

Extractable $\mathrm{N}$ concentration in soil did not vary among sampling periods with an overall mean value of $7.5 \mu \mathrm{g} \mathrm{N} \mathrm{g}^{-1}$ soil and individual treatment means ranging from 2.9-10.6 $\mu \mathrm{g} \mathrm{N} \mathrm{g}^{-1}$ soil. The correlation of extractable $\mathrm{N}$ with soil water content was not as strong as that of extractable C (Table 5).

\section{Microbial biomass}

Chloroform fumigation and direct extraction of freshly sampled soil was used for biomass determination in this study. Tate et al. (1991) advocated the use of fresh rather than pre-incubated soil, favoring the more versatile extraction procedure for measuring soil microbial biomass, especially for pasture soils. Banerjee and Chapman (1996) reported the range of microbial biomass $\mathrm{C}$ as $902-1485 \mu \mathrm{g} \mathrm{g}^{-1}$ soil in sandy clay loam to clay loam grassland soils. Our values for biomass $C$ (Table 6) in this study on a fine sandy loam soil were much less $\left(209-629 \mu \mathrm{g} \mathrm{g}^{-1}\right.$ soil) and similar to their values for arable soil biomass $\mathrm{C}$ range (62-795 $\mu \mathrm{g} \mathrm{g}^{-1}$ soil). Microbial biomass $\mathrm{C}$ content varied signif- 
Table 4. Extractable $\mathrm{C}$ content in soil at the Brandon pasture study site

\begin{tabular}{|c|c|c|c|c|}
\hline \multirow[b]{2}{*}{ Sampling time } & \multirow[b]{2}{*}{ Grazing system } & \multicolumn{3}{|c|}{$\ldots \ldots \ldots \ldots$ Stocking rate $\ldots \ldots \ldots$} \\
\hline & & Light & Heavy & Mean \\
\hline \multirow{4}{*}{24 Oct. 1994} & & \multicolumn{3}{|c|}{$\ldots \ldots \ldots \ldots\left(\mu g^{-1}\right.$ soil $) \ldots \ldots$} \\
\hline & Continuous & 49.8 & 48.4 & 49.1 \\
\hline & Rotational & 46.9 & 46.1 & 46.5 \\
\hline & Mean & 48.4 & 47.4 & $47.9 \mathrm{a}$ \\
\hline \multirow[t]{3}{*}{24 May 1995} & Continuous & 51.4 & 50.5 & 51.0 \\
\hline & Rotational & 48.6 & 46.4 & 47.5 \\
\hline & Mean & 50.0 & 48.5 & $49.3 \mathrm{a}$ \\
\hline \multirow[t]{3}{*}{31 July 1995} & Continuous & 11.3 & 19.3 & 15.3 \\
\hline & Rotational & 7.1 & 16.7 & 11.9 \\
\hline & Mean & 9.2 & 18.0 & $13.6 b$ \\
\hline
\end{tabular}

$\mathrm{a}$, b Means within column differ $(\mathrm{P}<0.05)$ if followed by different letter

icantly $(\mathrm{P}<0.001)$ during the year, lowest in samples taken in summer, the driest time of the year, and higher in spring (Table 6). Although biomass $\mathrm{C}$ content in fall and spring did not significantly differ, biomass $\mathrm{C}$ was correlated significantly with field water content (Table 5). Appreciable seasonal fluctuations have also been observed by DeLuca and Keeney (1994) in prairie soils. Biomass C also had a significant positive relationship with the extractable $\mathrm{C}$ in soil (Table 5).

Like other soil parameters, microbial biomass $\mathrm{C}$ was not affected by grazing system (Table 6). In contrast, stocking rate had a significant $(P<0.07)$ impact on the soil biomass $\mathrm{C}$ content, which decreased at the high stocking rate. This impact is likely the result of increased stocking intensity decreasing the photosynthetic capacity of herbage and subsequent root development (Hart and Hoveland 1989). Langlands and Bennett (1973) observed that as stocking rate increases, nutrients located in the animal pool increase and those in the plant pool decrease. They found that as stocking rate increased, herbage availability, root weight, basal cover and soil pore space declined, but soil nutrient composition appeared to be unaffected by changes in stocking rate, especially in the surface soil. Decreased photoassimilated $\mathrm{C}$ input to the root might reduce microbial growth and lower soil microbial biomass $\mathrm{C}$ (Smith and Paul 1990). Microbial biomass is the most labile pool in soil and can be a rapid indicator of any changes in the soil management system (Carter 1986, Bosatta and Argen 1994).

Biomass $\mathrm{N}$ content was significantly $(\mathrm{P}<0.001)$ affected by the time of sampling but neither grazing system nor stocking rate had any significant impact (Table 7); although soil biomass $\mathrm{N}$ tended to decrease with increasing stocking rate. Like biomass $\mathrm{C}$, biomass $\mathrm{N}$ was positively correlated with soil water content and extractable $\mathrm{C}$, but not with extractable $\mathrm{N}$ (Table 5). This suggests that extracted $\mathrm{N}$ is derived from a different pool or additional pools than that of the soil microbial biomass N (Stockdale and Rees 1994).

\section{Nitrogen mineralization}

Mineralization patterns reflect changes in substrate availability, microbial activity, and the balance between gross mineralization and immobilization. Kinetic models furnish a mathematical description of net mineralization rates (Ellert and Bettany 1988). Cumulative net mineralization rates were fit to a first-order kinetic model (Stanford and Smith 1972). Models of mineralization kinetics are the attempt to demonstrate soil biological processes, rather than pure mathematical exercises in finding the best fitting curve (Ellert and Bettany 1988). The model may oversim-

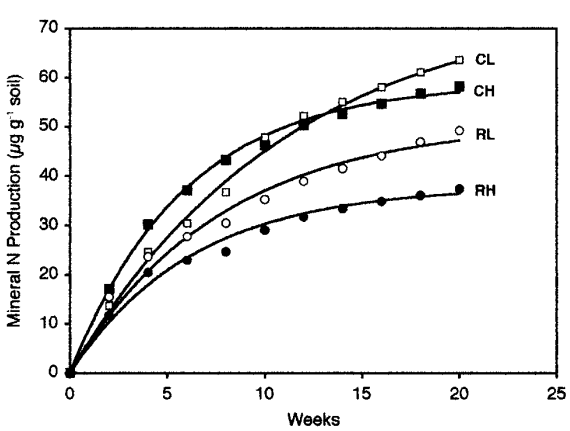

Fig. 1. Nitrogen mineralization kinetics of soils at the Brandon pasture study site. (CL $=$ Continuous grazing and Light stocking rate; $\mathbf{C H}=$ Continuous grazing and Heavy stocking rate; $\mathrm{RL}=$ Rotational grazing and Light stocking rate; $\mathbf{R H}=$ Roational grazing and Heavy stocking rate.

plify natural processes, but it should fit better than alternative models based on competing theories about the processes which produced the data set (Jowett et al. 1974). Although we did not investigate the seasonal effect on $\mathrm{N}$ mineralization potential, Ross et al. (1984) reported no evident seasonal pattern in $\mathrm{N}$ mineralization potential under grazed pasture soils of New Zealand. Our attempt was to observe whether grazing system and/or stocking rate had any effect on net mineral $\mathrm{N}$ production and rate of $\mathrm{N}$ mineralization. Net soil mineral $\mathrm{N}$ production (Fig. 1, Table 8) was higher under continuous grazing (mean $60.5 \mu \mathrm{g} \mathrm{g}^{-1}$ soil) than under rotational grazing (mean $43.0 \mu \mathrm{g} \mathrm{g}^{-1}$ soil) but, the difference was not significant $(\mathrm{P}=$ 0.34 ). Stocking rate also did not significantly affect mineral $\mathrm{N}$ production in soil. These results are consistent with Langlands and Bennet (1973) who found stocking rate did not significantly alter soil nutrient levels. Similar observations were also made in relation to effects of grazing and stocking treatments on $\mathrm{N}$ mineralization potential in soil (Fig. 1). Rates of $\mathrm{N}$ mineralization were highest during the

Table 5. Pearson's correlation coefficients between the soil parameters

\begin{tabular}{|c|c|c|c|c|c|c|c|}
\hline Parameters & Biomass $\mathrm{N}$ & Extract $\mathrm{C}$ & Extract $\mathrm{N}$ & Ary-lsulfatase & Acid Phosphatase & Al Phosp & Water \\
\hline Biomass C & $0.74 * * *$ & $0.71^{*} * *$ & -0.27 & $0.53 * *$ & $0.55 * *$ & -0.13 & $0.88 * * *$ \\
\hline Biomass N & & $0.56^{* *} *$ & -0.25 & 0.12 & 0.25 & -0.25 & $0.56^{* * *}$ \\
\hline Extract C & & & -0.31 & 0.36 & 0.17 & $0.45^{*}$ & $0.67 * * *$ \\
\hline Extract $\mathrm{N}$ & & & & -0.42 & -0.16 & 0.15 & $0.43^{*}$ \\
\hline Arylsulfatase & & & & & $0.44 *$ & 0.26 & $0.68 * * *$ \\
\hline Ac Phosp & & & & & & -0.21 & $0.68 * * *$ \\
\hline Al Phosp & & & & & & & -0.23 \\
\hline
\end{tabular}

$*, * *, * * *$ represent statistically significant at $\mathrm{p}<0.05, \mathrm{p}<0.01, \mathrm{p}<0.001$, respectively

Extract $\mathrm{C}=$ Extractable $\mathrm{C}$; Extract $\mathrm{N}=$ Extractable $\mathrm{N}$

Ac Phosp = Acid phosphatase; Al Phosp = Alkaline phosphatase 
Table 6. Soil microbial biomass $\mathrm{C}$ content at the Brandon pasture study site

\begin{tabular}{|c|c|c|c|c|}
\hline \multirow[b]{2}{*}{ Sampling time } & \multirow{2}{*}{$\begin{array}{l}\text { Grazing } \\
\text { System }\end{array}$} & \multicolumn{3}{|c|}{ Stocking rate } \\
\hline & & Light & Heavy & Mean \\
\hline \multirow{4}{*}{24 Oct. 1994} & & \multicolumn{3}{|c|}{$\ldots \ldots \ldots \ldots\left(\mathrm{g} \mathrm{C} \mathrm{g}^{-1}\right.$ soil $) \ldots \ldots$} \\
\hline & Continuous & 612 & 456 & 534 \\
\hline & Rotational & 557 & 525 & 541 \\
\hline & Mean & 585 & 491 & $538 \mathrm{a}$ \\
\hline \multirow[t]{3}{*}{24 May 1995} & Continuous & 629 & 475 & 552 \\
\hline & Rotational & 576530 & 553 & \\
\hline & Mean & 603 & 503 & $553 \mathrm{a}$ \\
\hline \multirow[t]{3}{*}{31 July 1995} & Continuous & 350 & 209 & 280 \\
\hline & Rotational & 288 & 318 & 303 \\
\hline & Mean & 319 & 264 & $292 b$ \\
\hline
\end{tabular}

a,bMeans within column differ $(\mathrm{P}<0.05)$ if followed by different letter

Table 7. Soil microbial biomass $\mathbf{N}$ content at the Brandon study site

\begin{tabular}{|c|c|c|c|c|}
\hline \multirow[b]{2}{*}{ Sampling time } & \multirow{2}{*}{$\begin{array}{l}\text { Grazing } \\
\text { System }\end{array}$} & \multicolumn{3}{|c|}{ Stocking rate } \\
\hline & & Light & Heavy & $\overline{\text { Mean }}$ \\
\hline \multirow{4}{*}{24 Oct. 1994} & & $\ldots$ & $\mathrm{g} \mathrm{g} \mathrm{g}^{-1}$ & $\ldots$ \\
\hline & Continuous & 63.8 & 66.2 & 65.0 \\
\hline & Rotational & 99.6 & 67.8 & 83.7 \\
\hline & Mean & 81.6 & 67.0 & $74.3 \mathrm{a}$ \\
\hline 24 May 1995 & Continuous & 70.7 & 52.1 & 61.4 \\
\hline \multirow{5}{*}{31 July 1995} & Rotational & 51.1 & 38.3 & 44.7 \\
\hline & Mean & 60.9 & 45.2 & $53.1 \mathrm{a}$ \\
\hline & Continuous & 28.2 & 19.3 & 23.8 \\
\hline & Rotational & 15.7 & 27.2 & 21.5 \\
\hline & Mean & 22.0 & 23.3 & $22.7 b$ \\
\hline
\end{tabular}

a,bMeans within column differ $(\mathrm{P}<0.05)$ if followed by different letter

Table 8. Kinetic description of $\mathbf{N}$ mineralization rate of soils collected from the Brandon Pasture study.

\begin{tabular}{|c|c|c|c|c|c|c|}
\hline Grazing System & Stocking Rate & $\mathrm{N}_{\min }$ & $\mathrm{N}_{\mathrm{O}}$ & $\mathrm{k}$ & Regression Equation & $\begin{array}{l}\text { Coefficient of } \\
\text { Determination }\end{array}$ \\
\hline & & $\left(\mu \mathrm{g} \mathrm{g}^{-1}\right)$ & \multicolumn{2}{|c|}{$\left(\mu \mathrm{g} \mathrm{g}^{-1}\right)\left(w^{-1}\right)$} & & \\
\hline Continuous & Light & 63 & 76 & 0.09 & $\mathrm{~N}_{\min }=76\left(1-\mathrm{e}^{-0.09 \mathrm{t}}\right)$ & 0.99 \\
\hline Continuous & Heavy & 58 & 59 & 0.17 & $\mathrm{~N}_{\min }=59\left(1-\mathrm{e}^{0.17 \mathrm{t}}\right)$ & 0.99 \\
\hline Rotational & Light & 49 & 51 & 0.13 & $\mathrm{~N}_{\min }=51\left(1-\mathrm{e}^{0.13 \mathrm{t}}\right)$ & 0.98 \\
\hline Rotational & Heavy & 37 & 38 & 0.16 & $\mathrm{~N}_{\min }=38\left(1-\mathrm{e}^{0.16 \mathrm{t}}\right)$ & 0.99 \\
\hline
\end{tabular}

Table 9. Arylsulfatase activity in soil at the Brandon pasture study site

\begin{tabular}{|c|c|c|c|c|}
\hline \multirow[b]{2}{*}{ Sampling time } & \multirow{2}{*}{$\begin{array}{l}\text { Grazing } \\
\text { System }\end{array}$} & \multicolumn{3}{|c|}{ Stocking rate } \\
\hline & & Light & Heavy & Mean \\
\hline 24 Oct. 1994 & $\begin{array}{l}\text { Continuous } \\
\text { Rotational } \\
\text { Mean }\end{array}$ & $\begin{array}{l}---- \\
42.8 \\
47.7 \\
45.4\end{array}$ & $\begin{array}{l}\text { nitrophe } \\
31.9 \\
51.9 \\
41.9\end{array}$ & $\begin{array}{l}37.4 \\
49.8 \\
43.7 \mathrm{a}\end{array}$ \\
\hline 24 May 1995 & $\begin{array}{l}\text { Continuous } \\
\text { Rotational } \\
\text { Mean }\end{array}$ & $\begin{array}{l}90.5 \\
89.1 \\
89.8\end{array}$ & $\begin{array}{l}72.5 \\
69.4 \\
71.0\end{array}$ & $\begin{array}{l}81.5 \\
79.3 \\
80.4 \mathrm{~b}\end{array}$ \\
\hline 31 July 1995 & $\begin{array}{l}\text { Continuous } \\
\text { Rotational } \\
\text { Mean }\end{array}$ & $\begin{array}{l}44.4 \\
44.1 \\
44.3\end{array}$ & $\begin{array}{l}43.4 \\
58.7 \\
51.1\end{array}$ & $\begin{array}{l}43.9 \\
51.4 \\
47.7 \mathrm{a}\end{array}$ \\
\hline
\end{tabular}

a, b Means within column differ $(\mathrm{P}<0.05)$ if followed by different letter

first 2 weeks of incubation and decreased with time as the labile organic $\mathrm{N}$ was depleted. The cumulative mineral $\mathrm{N}$ produced was usually lower than the estimated potential mineralizable $\mathrm{N}$ after 20 weeks of incubation, indicating some of the organic $\mathrm{N}$ fraction was still available for further mineralization (Table 8). The values of the rate constant $(\mathrm{k})$ range from 0.09 to $0.17 \mathrm{wk}^{-1}$ under continuous grazing (mean $0.13 \mathrm{wk}^{-1}$ ) and 0.13 to $0.16 \mathrm{wk}-1$ under rotational grazing system (mean $\left.0.145 \mathrm{wk}^{-1}\right)$

\section{Enzyme activities}

Both arylsulfatase and alkaline phosphatase activities showed significant $(\mathrm{P}<$ 0.05 ) differences between sampling times, but did not show similar times of minimum and maximum activity (Tables 9 and 10). Arylsulfatase activity was highest during spring and alkaline phosphatase activity was highest during summer, but acid phosphatase activity was not significantly affected by sampling time (Table 11). In contrast, Ross et al. (1995) reported non-significant seasonal fluctuations of arylsulfatase activity but very marked seasonal fluctuations of phosphatase activity in their soils. Seasonal variation in soil enzyme activities have been shown by Ladd (1978) as well. As found here, fluctuations in enzyme activity have not always coincided with season, and are often difficult to interpret. In our study, grazing systems and stocking rates did not significantly impact arylsulfatase (Table 9) and alkaline phosphatase activities (Table 10) but acid phosphatase activity was significantly $(\mathrm{P}<0.03)$ decreased under heavy stocking compared to light stocking (Table 11). Grazing system had no significant effect on the acid phosphatase activity. Arylsulfatase and acid phosphatase activities were correlated significantly and positively with soil water and biomass $\mathrm{C}$ (Table 5), whereas alkaline phosphatase activity had no significant relationship with soil water and biomass C. Soil enzymes are probably derived to a considerable extent from soil microorganisms (Ladd 1978). In this study arylsulfatase and acid phosphatase were correlated with microbial biomass $\mathrm{C}$ but alkaline phosphatase was not (Table 5).

Overall, at this site seasonal fluctuations occurred in the microbial and biochemical properties reported here. In general, these fluctuations were mainly independent of the variations in soil organic matter content (Ross et al. 1984) but were more closely related to soil water content. Of the parameters examined here, $\mathrm{N}$ mineralization is perhaps the most useful in assessing the productivity of the site as it is primarily an assessment availability and quality ( $\mathrm{C}: \mathrm{N}$ ratio) of mineralizable substrates. Mineralizable N was lower under rotational than under continuous grazing. Measures of biomass $\mathrm{C}$ and $\mathrm{N}$ represent both the catalytic potential of the soil and a measure of substrate availability. The initial data does suggest increased stock- 
Table 10. Alkaline phosphatase activity in soil at the Brandon pasture study site

\begin{tabular}{|c|c|c|c|c|}
\hline \multirow[b]{2}{*}{ Sampling time } & \multirow{2}{*}{$\begin{array}{l}\text { Grazing } \\
\text { System }\end{array}$} & \multicolumn{3}{|c|}{ Stocking rate } \\
\hline & & Light & Heavy & Mean \\
\hline 24 Oct. 1994 & $\begin{array}{l}\text { Continuous } \\
\text { Rotational } \\
\text { Mean }\end{array}$ & $\begin{array}{l}---\cdot \\
152.9 \\
145.7 \\
149.3\end{array}$ & $\begin{array}{l}\text { itrophen } \\
128.4 \\
155.7 \\
142.1\end{array}$ & $\begin{array}{l}140.7 \\
140.7 \\
150.7 \\
145.7 \mathrm{a}\end{array}$ \\
\hline 24 May 1995 & $\begin{array}{l}\text { Continuous } \\
\text { Rotational } \\
\text { Mean }\end{array}$ & $\begin{array}{l}179.5 \\
156.5 \\
168.0\end{array}$ & $\begin{array}{l}142.2 \\
166.4 \\
154.3\end{array}$ & $\begin{array}{l}160.9 \\
161.5 \\
161.2 \mathrm{a}\end{array}$ \\
\hline 31 July 1995 & $\begin{array}{l}\text { Continuous } \\
\text { Rotational } \\
\text { Mean }\end{array}$ & $\begin{array}{l}175.5 \\
172.0 \\
173.7\end{array}$ & $\begin{array}{l}196.3 \\
198.2 \\
197.2\end{array}$ & $\begin{array}{l}185.9 \\
185.1 \\
185.5 b\end{array}$ \\
\hline
\end{tabular}

a, b Means within column differ $(\mathrm{P}<0.05)$ if followed by different letter

Table 11. Acid phosphatase activity in soil at the Brandon pasture study site

\begin{tabular}{|c|c|c|c|c|}
\hline \multirow[b]{2}{*}{ Sampling time } & \multirow{2}{*}{$\begin{array}{l}\text { Grazing } \\
\text { System }\end{array}$} & \multicolumn{3}{|c|}{ Stocking rate } \\
\hline & & Light & Heavy & Mean \\
\hline 24 Oct. 1994 & $\begin{array}{l}\text { Continuous } \\
\text { Rotational } \\
\text { Mean }\end{array}$ & $\begin{array}{l}-\ldots-- \\
190.1 \\
181.2 \\
185.6 \mathrm{a}\end{array}$ & $\begin{array}{l}\text { hitrophen } \\
171.1 \\
183.6 \\
177.4 \mathrm{~b}\end{array}$ & $\begin{array}{l}-180.6 \\
180.6 \\
182.4 \\
181.5\end{array}$ \\
\hline 24 May 1995 & $\begin{array}{l}\text { Continuous } \\
\text { Rotational } \\
\text { Mean }\end{array}$ & $\begin{array}{l}225.8 \\
212.4 \\
219.2 \mathrm{a}\end{array}$ & $\begin{array}{l}173.0 \\
170.8 \\
171.8 \mathrm{~b}\end{array}$ & $\begin{array}{l}199.4 \\
191.6 \\
195.5\end{array}$ \\
\hline 31 July 1995 & $\begin{array}{l}\text { Continuous } \\
\text { Rotational } \\
\text { Mean }\end{array}$ & $\begin{array}{l}200.0 \\
169.6 \\
184.8 \mathrm{a}\end{array}$ & $\begin{array}{l}92.4 \\
195.6 \\
144.0 \mathrm{~b}\end{array}$ & $\begin{array}{l}146.2 \\
182.6 \\
164.4\end{array}$ \\
\hline
\end{tabular}

a, b Means within row differ $(\mathrm{P}<0.05)$ if followed by different letter

ing rate decreases soil microbial biomass $\mathrm{C}$, mineralizable $\mathrm{N}$, and acid phosphatase activity. The measures of enzyme content are more difficult to interpret as they indicate potential enzyme activity under conditions of excess substrate. Enzyme activity in soil systems is often primarily limited by substrate availability (Burton and McGill 1991). Due to the limited duration of the investigation, limited number of replications, and high soil variability encountered in this study, it may not be advisable to recommend any particular grazing system and/or stocking rate favorable for the maintenance of soil biological quality. The high degree of variation observed might be anticipated in view of the distribution of nitrogen rich feces and urine in pasture systems. Longer-term investigation involving more frequent sampling with increased replication is needed to assess more completely the impact of grazing system or stocking rate on soil biological characteristics. However, these preliminary results indicate possible adverse effects of excessively high stocking on soil health or quality.

\section{Literature Cited}

Abacus Concepts. 1991. SuperAnova Users Guide. Version 1.11, Abacus Concepts, Berkeley, Calif.

Banerjee, M. R. and S.J. Chapman. 1996. The significance of microbial biomass sulfur in soil. Biol. Fertil. Soils. 22:116-125.

Bosatta, E. and G.I. Agren. 1994. Theoretical analysis of microbial biomass dynamics in soils. Soil Biol. Biochem. 26:143-148.

Burton, D.L. and W.B. McGill. 1991. Inductive and repressive effects of carbon and nitrogen on L-histidine ammonia-lyase activity in a black chernozemic soil. Soil Biol. Biochem. 23:939-946.

Campbell, C.A., B.H. Ellert, and Y.W. Jame. 1993. Nitrogen mineralization potential in soils. pp. 341-349. In: M.R. Carter (ed.) Soil Sampling and Methods of Analysis. Lewis Publishers, Ann Arbour, Mich.

Carter, M.R., 1986. Microbial biomass as an index for tillage-induced changes in soil biological properties. Soil and Tillage Res. 7: 29-40.

DeLuca, T.H. and D.R. Keeney. 1994. Soluble carbon and nitrogen pools of prairie and cultivated soils: seasonal variation. Soil Sci. Soc. Amer. J. 58:835-840.
Doran, J.W. and T.B. Parkin. 1994. Defining and assessing soil quality. pp. 3-21. In: J.W. Doran, D.C. Coleman, D.F. Bezdicek, and B.A. Stewart (eds.) Defining Soil Quality for a Sustainable Environment. Soil Sci. Soc. Amer. Special Publ. No. 35, Soil Sci. Soc. of America Inc., Madison, Wisc.

Ehrlich, W.A., E.A. Poywer, and L.E. Pratt. 1957. Report of reconnaissance soil survey of Carberry map sheet area. Soils Report No.7 Manitoba Dept. of Agr. and Immigration, $93 \mathrm{pp}$.

Ellert, B.H. and J.R. Bettany. 1988. Comparison of kinetic models for describing net sulfur and nitrogen mineralization. Soil Sci. Soc. Amer. J. 52:1692-1702.

Hart, R.H. and C.S. Hoveland. 1989. Objectives of grazing trials. pp. 1-5 In: G. C. Marten (ed.) Grazing Research: Design, Methodology, and Analysis. CSSA Special Publication No. 16, Madison, Wisc.

Herrick, J.E. and W.G. Whitford. 1995. Assessing the quality of rangeland soils: Challenges and opportunities. J. Soil Water Conser. 50:237-242.

Howarth, R.E. and B.P. Golpen. 1983 Improvement of forage quality through production management and plant breeding. Can. J. Plant Sci., 63, 895-902.

Jenkinson, D.S., 1988, Determination of microbial biomass carbon and nitrogen in soil. pp. 368-386. In: J.R. Wilson (ed.) Advances in nitrogen cycling in agricultural ecosystems. CAB, Wallingford.

Jowett, D., J.A. Browning, and B.C. Haning. 1974. Non-linear disease progress curves. pp. 115-136. In: J. Kranz (ed.) Epidemics of plant diseases-mathematical analysis and modelling. Springer-Verlag, New York, N.Y.

Jung, H.G., R.W. Rice, and L.J. Koong. 1985. Comparison of heifer weight gains and forage quality for continuous and short duration grazing systems. J. Range Manage. 38: 144-148.

Ladd, J.N. 1978. Origin and range of enzymes in soil. pp. 51-96. In: R.G. Burns (ed.) Soil Enzymes, Academic Press, London.

Langlands, J.P. and I.L. Bennett. 1973. Stocking intensity and pastoral production I. Changes in the soil and vegetation of a sown pasture grazed by sheep at different stocking rates. J. Agr. Sci., Camb. 81:193-204.

Magdoff, F. 1995. Soil quality and management. pp. 349-364. In: M.A. Altieri (ed.) Agroecology: The Science of Sustainable Agriculture, 2nd Edition., Westview Press, Boulder, Colo.

Ross, D.J., T.W. Speir, J.C. Cowling, and K.N. Whale. 1984. Temporal fluctuations in biochemical properties of soil under pasture. II. Nitrogen mineralization and enzyme activities. Aust. J. Soil Res. 22:319-330.

Ross, D.J., T.W. Speir, H.A. Kettles, and A.D. Mackay. 1995. Soil microbial biomass, $\mathrm{C}$ and $\mathrm{N}$ mineralization and enzyme activities in a hill pasture: influence of season and slow-release P and S fertilizer. Soil Biol. Biochem. 27:1431-1443. 
SAS, Institute, Inc. 1985. SAS user's guide: Statistics. Version 5 (ed.). SAS Institute, Inc., Cary, N.C., 956 pp.

Sharrow, S.H. 1983. Forage standing crop and animal diets under rotational vs. continuous grazing. J. Range Manage. 36:447-449.

Smith, J.L. and E.A. Paul. 1990. The significance of soil microbial biomass estimations. pp. 357-396. In: J.M. Bollag and G. Stotzky, (eds.) Soil Biochemistry, Marcel Dekker, Inc., New York, N.Y.

Speir, T.W., D.J. Ross, and V.A. Orchard. 1984. Spatial variability of biochemical properties in a taxonomically uniform soil under grazed pasture. Soil Biol. Biochem. 16:153-160.

Stanford, G. and S.J. Smith. 1972. Nitrogen mineralization potentials of soils. Soil Sci. Soc. Amer. Proc., 36:465-472.
Stockdale, E.A. and R.M. Rees. 1994. Relationship between biomass nitrogen and nitrogen extracted by other nitrogen availability methods. Soil Biol. Biochem. 26: 1213-1220.

Tabatabai, M.A., 1982. Soil enzymes. pp. 501-534. In: A.L. Page, R.H. Miller, and D.R. Keeney (eds.) Methods of Soil Analysis. Part 2. Chemical and Microbiological Properties, 2nd Edition, Amer. Soc. of Agron. Inc., Madison, Wisc.

Tate, K.R., D.J. Ross, A.J. Ramsay, and K.N. Whale. 1991. Microbial biomass and bacteria in two pasture soils: An assessment of measurement procedures, temporal variations, and the influence of $\mathrm{P}$ fertility status. Pl. Soil 132:233-241.

Voroney, R.P., J.P. Winter, and R.P. Beyaert. 1993. Soil microbial biomass $C$ and N pp. 277-286. In: M.R. Carter (ed.) Soil Sampling and Methods of Analysis, Lewis Publishers, Ann Arbor, Mich.
Walton, P.D., R. Martinez, and A.W. Bailey. 1981. A comparison of continuous and rotational grazing. J. Range Manage. 34:19-21.

Warren, S.D., S.D. Nevill, W.H. Balckburn, and N.E. Garza. 1986. Soil response to trampling under intensive rotational grazing. J. Range Manage. 50:1336-1340.

Wu, J., R.G. Joergensen, B. Pommerening, R. Chaussod, and P.C. Brookes. 1990. Measurement of soil microbial biomass $\mathrm{C}$ by fumigation-extraction - an automated procedure. Soil Biol. Biochem. 22:1167-1169.

Yeomans, J.C. and J.M. Bremner. 1988. A rapid and precise method for routine determination of organic carbon in soil. Comm. in Soil Sci. Plant Anal. 19:1467-1476. 